\title{
A prospective study on effect of maternal BMI on fetal outcome
}

\section{Bali Ram Sharma, Reena Sharma, Poojan Dogra*}

Department of Obstetrics and Gynecology, SLBS GMC Mandi at Nerchowk, Himachal Pradesh, India

Received: 05 May 2018

Accepted: 29 May 2018

\section{*Correspondence:}

Dr. Poojan Dogra,

E-mail: drpoojandogramarwaha@gmail.com

Copyright: (c) the author(s), publisher and licensee Medip Academy. This is an open-access article distributed under the terms of the Creative Commons Attribution Non-Commercial License, which permits unrestricted non-commercial use, distribution, and reproduction in any medium, provided the original work is properly cited.

\section{ABSTRACT}

Background: The extremes of BMI have a major impact on pregnancy outcomes. The objective of this study was to assess antenatal, intra-partum complications, perinatal outcome in pregnant women with high BMI.

Methods: This study was conducted in Department of Obstetrics and Gynecology, Kamla Nehru State Hospital for Mother and Child IGMC Shimla, on 1000 women attending antenatal outpatient department over one year w.e.f. 0105-2011 to 30-04-2012. Detailed information regarding different variables like maternal age, parity, education status, occupation socioeconomic status and weight gain during pregnancy were recorded on a proforma, master chart framed and analyzed using Student's t test.

Results: The study observed that both being overweight and underweight predisposes women to complicated pregnancies. The incidence of preterm is more in underweight women and post- dated deliveries increased with increase in BMI. Incidence of stillbirth was maximum in obese women. Incidence of low birth weight babies was more among underweight and the incidence of macrosomia was more in obese women.

Conclusions: Maternal BMI have strong association with pregnancy complications and outcome.

Keywords: BMI, Fetal outcome, Maternal weight, Period of gestation

\section{INTRODUCTION}

During the last two decades, there has been an alarming rise in the incidence of obesity all over the world. India is now facing a double burden of this disease with undernutrition and underweight on one side, and a rapid upsurge in obesity and overweight, particularly in the urban settings on the other side. The National Family Health Surveys (NFHS) in India indicated an increase in the obesity from $10.6 \%$ in $1998-1999$ to $14.8 \%$ in $2005-$ 2006 , while there was only a marginal decrease in the incidence of underweight from $36.2 \%$ (1998-1999) to $33.0 \%$ (2005-2006). ${ }^{1}$ Both lean and obese women carry a risk for adverse pregnancy outcomes. ${ }^{2}$ Maternal body mass index (BMI) is one of the most important predictor of nutritional status of pregnant woman. Both nutritional intake and maternal weight are modifiable factors which can influence pregnancy outcome. ${ }^{3}$ In India, 26\% of pregnant women are overweight and $8 \%$ are obese. ${ }^{4}$ Furthermore, it has been showed that low APGAR score and perinatal deaths are more common in neonates of obese women., ${ }^{2,5}$ The rising rate of obesity is a major public health concern in India as very few females come for preconception counseling so estimation of prepregnancy weight record is not available. Women from rural area are not even aware of their weights. ${ }^{6}$ So, in view of these factors we decided to conduct this study to correlate the early pregnancy BMI with fetal outcome.

The objectives of the study were to determine the maternal and fetal risks of adverse pregnancy outcome in relation to the extremes of maternal body mass index.

\section{METHODS}

It is a prospective observational study conducted in Department of Obstetrics and Gynecology, Kamla Nehru 
State Hospital for Mother and Child IGMC Shimla, on 1000 women attending antenatal outpatient department over one year w.e.f. 01-05-2011 to 30-04-2012. On first antenatal visit before 12 weeks of gestation weight was measured by a calibrated scale accurate up to $0.5 \mathrm{~kg}$ and height was measured in meters and BMI was calculated in $\mathrm{Kg} / \mathrm{m}^{2}$. For each mother BMI was calculated at first visit before 12 weeks of gestation, parity, POG, socioeconomic status, education and occupation was noted. Fetal outcome in form of live birth, stillbirth or intrauterine death, birth weight, APGAR at 5 minutes and admission to NICU were correlated to maternal variables. Detail information regarding different variables like maternal age, parity, education status, occupation socioeconomic status and weight gain during pregnancy was recorded on proforma and statistical testing was performed using Student's t test. Nominal categorical data between the groups were compared by Chi-square test and $p$ value $<0.05$ was considered significant.

\section{Women in study group were divided in four groups according to BMI:-}

- Group A- Underweight- $<18.5 \mathrm{~kg} / \mathrm{m}^{2}$

- Group B- Normal BMI- 18.5 to $24.9 \mathrm{~kg} / \mathrm{m}^{2}$

- Group C- Overweight- 25 to $29.9 \mathrm{~kg} / \mathrm{m}^{2}$

- Group D- Obese- $>30 \mathrm{~kg} / \mathrm{m}^{2}$

Parameters evaluated during study were:-

- Fetal outcome- live birth, still birth or intrauterine death.

- Birth weight of neonate- very low, low, normal or macrosomia.
- $\quad$ APGAR at 5 minutes.

- Newborns admitted to NICU.

\section{Exclusion criteria}

Women with multiple gestation, DM, essential hypertension, cardiovascular disease, renal disease, pulmonary disease and autoimmune disorders.

\section{RESULTS}

On the basis of the BMI, out of the 1000 women, Group A, $92(9.2 \%)$ were underweight and Group B, 486 (48.6\%) belonged to the normal weight category, while Group C, 375 (37.5\%) and Group D, 47 (4.7\%) women were from the overweight and the obese categories respectively (Table1).

Table1: Distribution of women according to BMI.

\begin{tabular}{|c|c|c|c|c|}
\hline Group & $\begin{array}{l}\text { BMI } \\
\text { Category }\end{array}$ & $\begin{array}{l}\text { BMI } \\
\left(\mathrm{kg} / \mathrm{m}^{2}\right)\end{array}$ & $\begin{array}{l}\text { Number } \\
\text { of Pt. }\end{array}$ & Percentage \\
\hline A & $\begin{array}{l}\text { Under } \\
\text { Weight }\end{array}$ & $<18.5$ & 92 & 9.2 \\
\hline B & $\begin{array}{l}\text { Normal } \\
\text { Weight }\end{array}$ & $\begin{array}{l}18.5- \\
24.9\end{array}$ & 486 & 48.6 \\
\hline $\mathrm{C}$ & $\begin{array}{l}\text { Over } \\
\text { Weight }\end{array}$ & $25-29.9$ & 375 & 37.5 \\
\hline D & Obese & $>30$ & 47 & 4.7 \\
\hline
\end{tabular}

There were significantly more preterm deliveries 16 (17.4\%) in group A as compared to group B 6.4\%, group C $6.9 \%$ and group D $6.4 \%$. There were significantly more $(\mathrm{p}=0.0230)$ post-term deliveries in obese group $\mathrm{D}$ as compared to group B.

Table 2: Period of gestation in relation to $\mathrm{BMI}$ at delivery (total women=1000).

\begin{tabular}{|lllll|}
\hline BMII group & A & B & C & D \\
\hline Number of women & 92 & 486 & 375 & 47 \\
\hline Abortion (up-to 24 weeks) & $5(5.4 \%)$ & $25(5.1 \%)$ & $36(9.6 \%)$ & $6(12.8 \%)$ \\
\hline Preterm $(24$ to $<37$ weeks) & $16(17.4 \%)$ & $31(6.4 \%)$ & $26(6.9 \%)$ & $3(6.4 \%)$ \\
\hline Term $(>37$ to $<40$ weeks) & $65(70.7 \%)$ & $380(78.2 \%)$ & $264(70.4 \%)$ & $28(59.6 \%)$ \\
\hline Post-term $(>40$ weeks) & $6(6.5 \%)$ & $50(10.3 \%)$ & $49(13.1 \%)$ & $10(21.3 \%)$ \\
\hline
\end{tabular}

Table 3: Birth weight of neonate in relation to BMI (total women=1000).

\begin{tabular}{|llll|l|}
\hline BMII group & A & B & C & D \\
\hline Number of women & 92 & 486 & 375 & 47 \\
\hline VLBW $(<1.5 \mathrm{~kg})$ & $6(6.5 \%)$ & $20(4.1 \%)$ & $15(4.0 \%)$ & $1(2.1 \%)$ \\
\hline LBW $(1.5-2.5 \mathrm{~kg})$ & $28(30.4 \%)$ & $56(11.5 \%)$ & $21(5.6 \%)$ & $1(2.1 \%)$ \\
\hline Normal weight $(>2.5-4 \mathrm{~kg})$ & $57(62.0 \%)$ & $401(82.5 \%)$ & $328(87.5 \%)$ & $40(85.1 \%)$ \\
\hline Macrosomic $(>4 \mathrm{~kg})$ & $1(1.1 \%)$ & $9(1.9 \%)$ & $11(2.9 \%)$ & $5(10.6 \%)$ \\
\hline
\end{tabular}

There was significantly low mean birth weight of neonates in group A as compared to group B $(\mathrm{p}=0.001)$ and mean birth weight in group $\mathrm{C}(\mathrm{p}=0.024)$ and group $\mathrm{D}$ $(\mathrm{p}=0.005)$ was higher than group $\mathrm{B}$.
The incidence of live births, stillbirths and IUD was comparable in all the BMI groups. In group A there was no stillbirth only $1.1 \%$ had IUD. Group B $0.6 \%$ had stillbirth and $0.6 \%$ had IUD also. In group $\mathrm{C} 0.5 \%$ had stillbirth and $1.1 \%$ had IUD and group D $2.1 \%$ had 
stillbirth and $2.1 \%$ had IUD also. In group A there were $2.2 \%$ neonates who had APGAR $<4$ and $2.3 \%$ in group $\mathrm{B}, 2.4 \%$ in group $\mathrm{C}$ and $2 \%$ in group $\mathrm{D}$. In group A $4.3 \%$ , group B 3.7\%, group C $4.8 \%$ and group D $4 \%$ neonates had APGAR between 4-7.As compared to $94 \%$ neonates in group B who had APGAR >7 group A had 93.5\%, group $C$ had 92.85 and group D had $94 \%$ neonates. APGAR score of neonates at 5 minutes was comparable in all BMI categories. It was observed that there were $8.7 \%$ neonates in group A, $7.8 \%$ in Group B, 9.6\% in group $\mathrm{C}$ and $13 \%$ in group $\mathrm{D}$ who were admitted to NICU which were comparable in all groups.

Table 4: Neonatal outcome of women according to BMI (total women=1000).

\begin{tabular}{|c|c|c|c|c|}
\hline BMI group & $\mathbf{A}$ & B & C & D \\
\hline $\begin{array}{l}\text { Number of } \\
\text { women }\end{array}$ & 92 & 486 & 375 & 47 \\
\hline Still Birth & $0(0 \%)$ & $\begin{array}{l}3 \\
(0.6 \%)\end{array}$ & $\begin{array}{l}2 \\
(0.5 \%)\end{array}$ & $\begin{array}{l}1 \\
(2.1 \%)\end{array}$ \\
\hline IUD & $\begin{array}{l}1 \\
(1.1 \%)\end{array}$ & $\begin{array}{l}3 \\
(0.6 \%)\end{array}$ & $\begin{array}{l}4 \\
(1.1 \%)\end{array}$ & $\begin{array}{l}1 \\
(2.1 \%)\end{array}$ \\
\hline APGAR <4 & $\begin{array}{l}2 \\
(2.2 \%)\end{array}$ & $\begin{array}{l}11 \\
(2.3 \%)\end{array}$ & $\begin{array}{l}9 \\
(2.4 \%)\end{array}$ & $\begin{array}{l}1 \\
(2.1 \%)\end{array}$ \\
\hline APGAR 4-7 & $\begin{array}{l}4 \\
(4.3 \%)\end{array}$ & $\begin{array}{l}18 \\
(3.7 \%)\end{array}$ & $\begin{array}{l}18 \\
(4.8 \%)\end{array}$ & $\begin{array}{l}2 \\
(4.3 \%)\end{array}$ \\
\hline $\begin{array}{l}\text { NICU } \\
\text { admission }\end{array}$ & $\begin{array}{l}8 \\
(8.7 \%)\end{array}$ & $\begin{array}{l}3 \\
(7.8 \%)\end{array}$ & $\begin{array}{l}36 \\
(9.6 \%)\end{array}$ & $\begin{array}{l}47 \\
(13 \%)\end{array}$ \\
\hline
\end{tabular}

\section{DISCUSSION}

Obesity has become an epidemic worldwide. WHO has declared obesity as a major killer disease of the millennium at par with malnutrition and HIV. BMI provides simple numeric measure of a person's fatness or thinness. Study observed that both being overweight and underweight predisposes women to complicated pregnancies. $^{7}$ The incidence of preterm is more in underweight women probably due to the fact that they belong to low socio-economic status with low educational standard, more manual work and are less aware for their health. Post- dated deliveries increased with increase in BMI which could be related to the sedentary life style of obese women. Mean gestational age at delivery was comparable in all the study groups in present study. Similar observation was made by Crane et al and Choi et al. Incidence of stillbirth was $0.0 \%$ in group $\mathrm{A}, 0.6 \%$ in group $\mathrm{B}, 0.5 \%$ in group $\mathrm{C}$ and $2 \%$ in group D. ${ }^{8,9}$ Incidence of live birth $98.5 \%$ reflects a good perinatal care at the institute. Live births were comparable in all BMI groups. APGAR score at 5 minutes $<7$ in present study was more as compared to study by Crane et al and Arrowsmith et al which could probably be explained by the more sophisticated and intensive intra-partum monitoring facilities in western countries. ${ }^{7}$ Neonates admitted to NICU in present study were comparable to study by Crane et al and El-Gilany et al in groups $\mathrm{A}, \mathrm{B}$ and $\mathrm{C}$, but in group D admission to
NICU was more in present study this can also be due to better perinatal care in western countries. ${ }^{9,10}$ Low birth weight babies were more among underweight women due to poor nutrition and lack of health awareness in this group. ${ }^{9}$ The incidence of macrosomia was more in group $\mathrm{D}$ which could be attributed to better nutrition, healthcare and increased incidence of gestational diabetes in this group. Our study has shown that macrosomia or babies with higher birth weight is common in obese and overweight women. Similar results were obtained with other studies conducted by Isaacs et al and Bianco et al. ${ }^{11,12}$

\section{CONCLUSION}

The study has shown an association between maternal weight and pregnancy outcome. It is concluded that obesity was associated with increased complication such as abortions, gestational diabetes, post-term delivery and fetal macrosomia etc. In underweight women adverse outcome were increased incidence of pre-term deliveries and low birth weight babies. The management should include the pre-pregnancy counseling in eligible women.

\section{Funding: No funding sources}

Conflict of interest: None declared

Ethical approval: The study was approved by the Institutional Ethics Committee

\section{REFERENCES}

1. International Institute for population sciences. Key Indicators for India from NFHS-3. Available at: http://www.nfhsindia.org/pdf/India.pdf. Published 2006.

2. Sahu MT, Agarwal A, Das V, Pandey A. The impact of the maternal body mass index on the obstetric outcome. J. Obstet. Gynaecol Res. 2007;33(5):655-9.

3. Nutrition during Pregnancy and Lactation. Implementation Guide. Available at: http://www.nap.edu/openbook.php?record_id=1984. Accessed on 2011 Apr 25.

4. O'Brien TE, Ray JG, Chan WS. Maternal body mass index and the risk of preeclampsia: A systematic overview. Epidemiol. 2003;14:368-74.

5. Scott-Pillai R, Spence D, Cardwell CR, Hunter A, Holmes VA. The impact of body mass index on maternal and neonatal outcomes: A retrospective study in a UK obstetric population, 2004-2011. BJOG. 2013;120:932-9.

6. Kopelman PG. Causes and consequences of obesity. Med Int. 1994;22:385-8.

7. Arrowsmith S, Wary S, Quenby S. Maternal obesity and labour complications following induction in a prolonged pregnancy. $\mathrm{Br} \mathrm{J}$ Obstet Gynaecol. 2011;118:578-88.

8. Bhattcharya S, Campbell MD, Liston WA. Effect of Body Mass Index on pregnancy outcomes in nulliparous women delivering singleton babies. BMC Public Health. 2007;7:168. 
9. Crane JMG, White J, Murphy P, Burrage L, Hutchens D. The Effect of Gestational weight Gain by Body Mass Index on Maternal and Neonatal Outcome. J Obstet Gynaecol Can. 2009;31(1):28-35.

10. El- Gilany AH, Hammad S. Body Mass Index and Obstetric Outcome in Soudi Arabia:a prospective cohort study. Ann Soudi Med. 2010;30(5):376-80.

11. Isaacs JD, Magann EF, Martin RW, Chauhan SP, Morrison JC. Obstetric challenges of massive obesity complicating pregnancy. J Perinatol. 1994;14:10-4.
12. Bianco AT, Smilen SW, Davis Y, Lopez S, Lapinski R, Lockwood CJ. Pregnancy outcome and weight gain recommendations for the morbidly obese woman. Obstet Gynecol. 1998;91:97-102.

Cite this article as: Sharma BR, Sharma R, Dogra P. A prospective study on effect of maternal BMI on fetal outcome. Int J Reprod Contracept Obstet Gynecol 2018;7:2782-5. 